\title{
EVALUATING DISSOLVED INORGANIC CARBON CYCLING IN A FORESTED LAKE WATERSHED USING CARBON ISOTOPES
}

\author{
RAMON ARAVENA ${ }^{1}$, S. L. SCHIFF', S. E. TRUMBORE ${ }^{2}$, P. J. DILLON ${ }^{3}$ and \\ RICHARD ELGOOD
}

\begin{abstract}
Dissolved inorganic carbon (DIC) is the main acid buffer in forested lake watersheds in Canada. We used carbon isotopes $\left({ }^{13} \mathrm{C},{ }^{14} \mathrm{C}\right)$ to evaluate the production and cycling of DIC in an acid-sensitive lake watershed of the Precambrian Shield. Soil $\mathrm{CO}_{2}$, groundwater and stream DIC were characterized chemically and isotopically. Soil $\mathrm{CO}_{2}$ concentration profiles reflect both changes in production and in losses due to diffusion. $\delta^{13} \mathrm{C}$ soil $\mathrm{CO}_{2}$ profiles $\left(\delta^{13} \mathrm{C}\right.$ values of $-23 \%$ in summer, slightly enriched during the fall and $-25 \%$ during the winter) are a reflection of the isotopic composition of the sources and changes in isotopic fractionation due to diffusion. Carbon isotopic composition $\left({ }^{13} \mathrm{C},{ }^{14} \mathrm{C}\right)$ of the groundwater and stream DIC clearly indicate that weathering of silicates by soil $\mathrm{CO}_{2}$ is the main source of DIC in these watersheds. ${ }^{14} \mathrm{C}$ data show that, in addition to recent groundwater, an older groundwater component with depleted ${ }^{14} \mathrm{C}$ activity is also present in the bedrock. The carbon isotope pattern in the groundwater also implies that, besides the main springtime recharge events, contributions to the groundwater may also occur during late winter/early spring.
\end{abstract}

\section{INTRODUCTION}

Growing concerns about the global carbon cycle and the natural and anthropogenic sources and sinks of carbon have fostered renewed research interest in the cycling of carbon in natural systems (e.g., Quay et al. 1986; Hedges et al. 1986; Cicerone \& Oremland 1988). Northern temperate forest watersheds cover a large part of northern Canada. An understanding of the carbon cycle in these systems is critical in predicting the anthropogenic influences, such as acid rain and climate modifications, on the cycling and fluxes of carbon.

This paper constitutes part of an ongoing research project whose main objective is the evaluation of carbon cycling in Harp Lake, a forested watershed in the acid-sensitive region of the Precambrian Shield, southeastern Ontario, Canada (Schiff et al. 1990; Aravena \& Schiff 1990; Trumbore et al. 1992). Our approach involves the use of carbon isotopes, ${ }^{13} \mathrm{C}$ and ${ }^{14} \mathrm{C}$, as tracers to evaluate sources and sinks of the main carbon pools: dissolved inorganic carbon (DIC), dissolved organic carbon (DOC) and solid organic carbon (SOC). We discuss here the sources of DIC in groundwater and streams of a forested watershed of the Precambrian Shield. DIC production and cycling are important in the acid neutralization capacity of these systems because DIC is the main acid buffer in these acid-sensitive lake watersheds.

\section{Study Area}

Harp Lake, located in the District of Muskoka, Ontario $\left(45^{\circ} 23^{\prime} \mathrm{N}, 79^{\circ} 08^{\prime} \mathrm{W}\right)$ (Fig. 1), is one of several Precambrian Shield lakes studied as part of the Acid Precipitation in Ontario Study (APIOS) (Dillon et al. 1978; Scheider, Jeffries \& Dillon 1979). Harp Lake catchment, with an area of 506 ha, is forested by mixed deciduous coniferous forest. The underlying bedrock consists primarily (68\%) of biotite and horneblende gneiss with amphibolite and schist in the western portion of the basin (Jeffries \& Snyder 1983). The overburden consists of a minor till plain and rock ridges (88\%), with wetlands covering the rest of the catchment. The dominant soils are weakly developed podzols formed upon the thin, sandy basal tills. The essential mineralogy of the soils should be similar to Plastic Lake watershed, located in the same area, the dominant minerals

\footnotetext{
${ }^{1}$ Waterloo Centre for Groundwater Research, University of Waterloo, Waterloo, Ontario N2L 3G1 Canada ${ }^{2}$ Center for Accelerator Mass Spectrometry, Lawrence Livermore National Laboratory, Livermore, California 94550 USA ${ }^{3}$ Dorset Research Centre, Ministry of the Environment, Dorset, Ontario P0A 1E0 Canada
} 
of which include quartz, plagioclase feldspar, potassium feldspar, amphibole, vermiculite and iron oxides (Kirkwood \& Nesbitt 1991).

The Harp Lake basin is divided into six small subcatchments, each instrumented with a gauging weir (Fig. 1). The groundwater and soil $\mathrm{CO}_{2}$ studies were mainly carried out in Harp subcatchment 4, which has been the focus of extensive hydrological and geochemical studies (e.g., Seip et al. 1985; Rustad et al. 1986; Dankevy et al., in press).

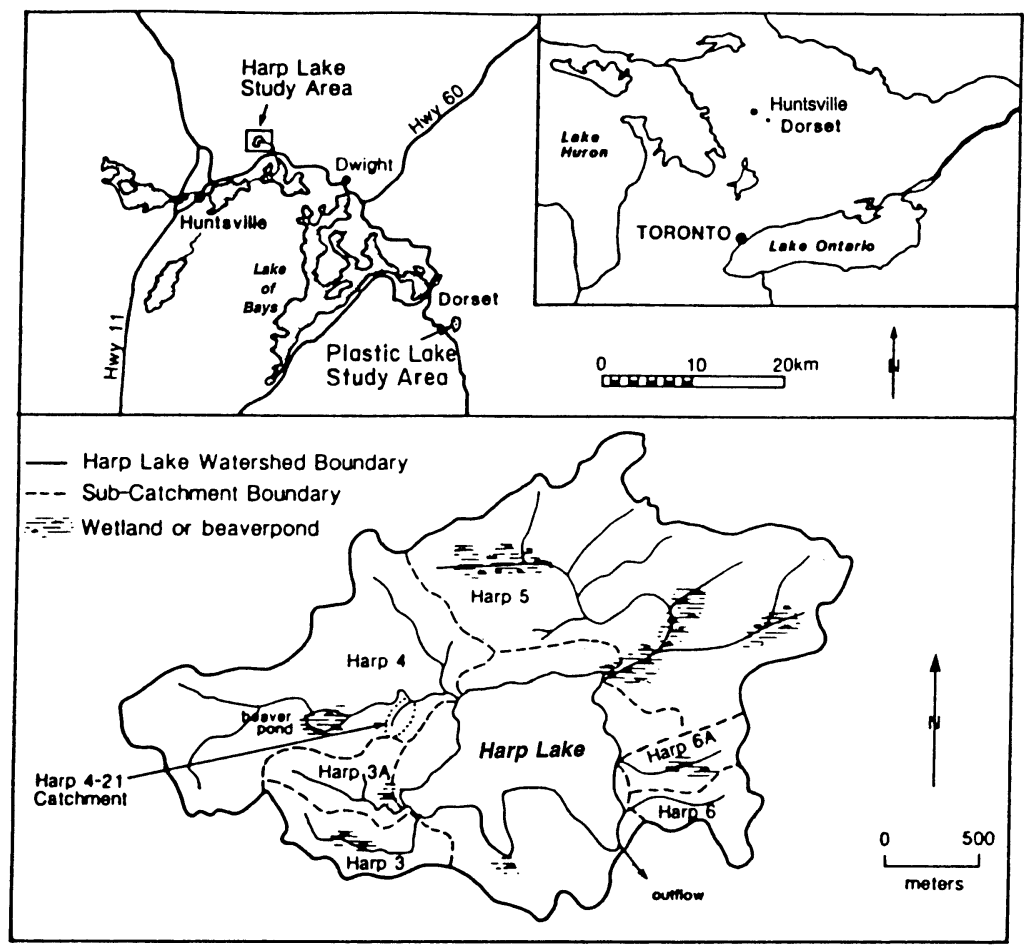

Fig. 1. Study area, Harp Lake watershed

\section{Methodology}

We collected soil $\mathrm{CO}_{2}$ samples for $\mathrm{CO}_{2}$ concentration and ${ }^{13} \mathrm{C}$ analysis on a monthly basis, using a nest of individual metal probes that penetrate the first $100 \mathrm{~cm}$ of the soil. The probe inlets were at $10-\mathrm{cm}$ intervals. Samples were collected in glass syringes, stored under water, refrigerated and analyzed within a few days after sampling. Standard gas chromatographic techniques were used for analyzing $\mathrm{CO}_{2}$ concentration at the Water Quality Laboratory, University of Waterloo. For ${ }^{13} \mathrm{C}$ analyses, the $\mathrm{CO}_{2}$ was purified in a standard vacuum line and run in a VG Micromass 903 or a VG PRISM. These analyses were carried out at the Environmental Isotope Laboratory (EIL), University of Waterloo, with an analytical reproducibility better than $0.2 \%$. ${ }^{13} \mathrm{C}$ analyses are reported using the $\delta$ notation defined as

$$
\delta^{13} \mathrm{C}=\left[\left(\mathrm{R}_{\text {sample }} / \mathrm{R}_{\text {standard }}\right)-1\right] * 1000
$$

where the R's are the ${ }^{13} \mathrm{C} /{ }^{12} \mathrm{C}$ ratio in the sample and international standard $\mathrm{PDB}$, respectively. 
We collected groundwater samples from wells located close to the recharge areas, in the middle of the basin and in discharge areas. Streams were sampled at the gauging weirs located at the bottom of each subcatchment, with the exception of Harp 4-21, which is located in the middle of the basin (Fig. 1). $\mathrm{CO}_{2}$ produced by direct acidification of the water was purified and subsampled for ${ }^{13} \mathrm{C}$ and ${ }^{14} \mathrm{C}$ analyses. ${ }^{13} \mathrm{C}$ analyses were carried out at EIL by mass spectrometry and ${ }^{14} \mathrm{C}$ analyzed at Lawrence Livermore National Laboratory by tandem accelerator mass spectrometry (AMS) (Davis et al. 1990). ${ }^{14} \mathrm{C}$ results are expressed in percent modern carbon (pMC) normalized to a $\delta^{13} \mathrm{C}$ of $-25 \%$ o PDB (Stuiver \& Polach 1977). Typical analytical errors are $\pm 1 \mathrm{pMC}$ for ${ }^{14} \mathrm{C}$.

\section{RESULTS AND DISCUSSION}

\section{Soil $\mathrm{CO}_{2}$}

Soil $\mathrm{CO}_{2}$ concentration profiles collected from spring 1990 (May) to the end of winter 1991 (March) show three distinct patterns (Fig. 2): first, an increase in $\mathrm{CO}_{2}$ concentration that reaches a maximum (1.2\%) at mid-summer; second, a decrease in $\mathrm{CO}_{2}$ concentration occurs between July and December, reaching a minimum concentration of $0.3 \%$; finally, we observed a slight increase from 0.3\%-0.5\% between December and March 1991. More than $1 \mathrm{~m}$ of snow covered the field area during this last period.

The $\mathrm{CO}_{2}$ trends shown in Figure 2 result from $\mathrm{CO}_{2}$ cycling in the soil zone. The sources of soil $\mathrm{CO}_{2}$ are root respiration and oxidation of organic matter (e.g., Solomon \& Cerling 1987). Thus, $\mathrm{CO}_{2}$ concentration in soils depends on the rate of production, which is a function of soil temperature and moisture content and rate of loss. (e.g., Dörr \& Münnich 1987). $\mathrm{CO}_{2}$ concentration

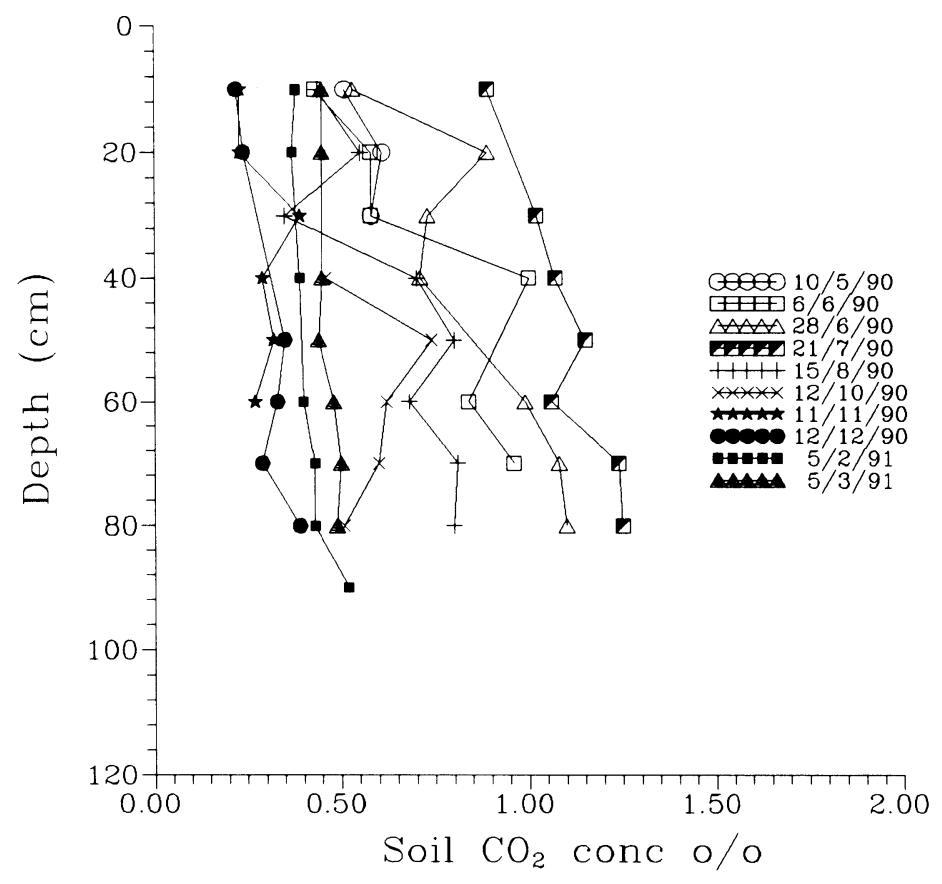

Fig. 2. Soil $\mathrm{CO}_{2}$ concentration profiles, Harp Lake watershed 
gradients with depth in a soil environment are mainly due to movement of $\mathrm{CO}_{2}$ from production zones to the atmosphere and toward the water table (e.g., Reardon, Allison \& Fritz 1979).

The soil $\mathrm{CO}_{2}$ concentration profiles at Harp Lake can be explained by an increase in $\mathrm{CO}_{2}$ production during the summer, a decrease in $\mathrm{CO}_{2}$ production from July to December, and finally, an accumulation of $\mathrm{CO}_{2}$ during winter, when the area is covered by snow. During winter, photosynthetic activity and microbiological respiration rates are at a minimum. However, the snow cover reduces the diffusive loss of soil $\mathrm{CO}_{2}$ to the atmosphere, explaining the slight increase in soil $\mathrm{CO}_{2}$ during the winter.

\section{${ }^{13} \mathrm{C}$ Composition of Soil $\mathrm{CO}_{2}$}

In the $\delta^{13} \mathrm{C}$ profiles for soil $\mathrm{CO}_{2}$ (Fig. 3 ), $\delta^{13} \mathrm{C}$ values are about $-22 \%$ during the summer, with a trend to more enriched values $(\sim-21 \%)$ in the early fall. This trend reverses from October, with $\delta^{13} \mathrm{C}$ values approaching $-25 \%$ during winter. These trends must be associated with processes that control the concentration of $\mathrm{CO}_{2}$ in soil environments.

The ${ }^{13} \mathrm{C}$ composition of soil $\mathrm{CO}_{2}$ is related to the isotopic composition of the sources (root respiration and oxidation of organic matter), which, in turn, is a function of the photosynthetic cycle of the vegetation and the isotopic fractionation that occurred during $\mathrm{CO}_{2}$ losses to the atmosphere by diffusion (Dörr \& Münnich 1980; Cerling 1984; Cerling et al. 1989). Plants that use the Calvin photosynthetic cycle $\left(\mathrm{C}_{3}\right.$ plants) are characterized by a range in $\delta^{13} \mathrm{C}$ between $-24 \%$ to $-29 \%$. Other plants that use the Hatch-Slack photosynthetic cycle $\left(C_{4}\right.$ plants $)$ range in $\delta^{13} \mathrm{C}$ values between $-10 \%$ to $-16 \%$ (Deines 1980 ).

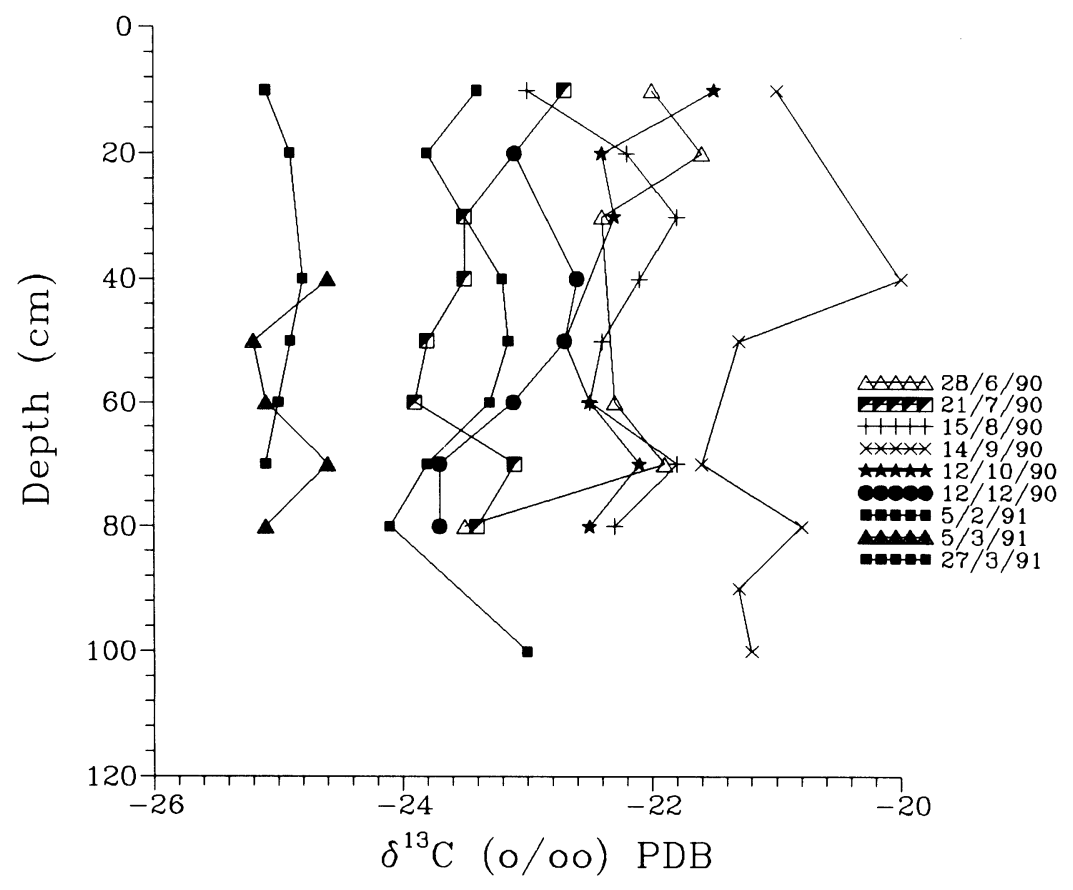

Fig. 3. Soil $\mathrm{CO}_{2} \delta^{13} \mathrm{C}$ profiles, Harp Lake watershed 
TABLE $1 .{ }^{13} \mathrm{C}$ and ${ }^{14} \mathrm{C}$ data of soil $\mathrm{CO}_{2}$ and tree leaves, Harp Lake catchment

\begin{tabular}{lccc}
\hline & Sampling date & $\begin{array}{l}\delta^{13} \mathrm{C} \% \\
(\mathrm{PDB})\end{array}$ & ${ }^{14} \mathrm{C}$ pMC \\
\hline Tree leaves & June/1990 & -28.0 & 117.9 \\
Soil $\mathrm{CO}_{2} 30 \mathrm{~cm}$ & August $/ 1990$ & -20.9 & 117.0 \\
& March/1991 & -24.9 & 116.4 \\
Soil $\mathrm{CO}_{2} 70 \mathrm{~cm}$ & August $/ 1990$ & -21.3 & 116.3 \\
& March/1991 & -25.1 & 119.7 \\
Atmospheric $\mathrm{CO}_{2}$ & August/1990 & -11.3 & 116.5 \\
\hline
\end{tabular}

Plants in the study area have $\delta^{13} \mathrm{C}$ values around $-28 \%$ (Table 1). Further, $\delta^{13} \mathrm{C}$ values for DOC in Harp Lake catchment water, which is related to the isotopic composition of the soil organic matter (SOM), range between $-25 \%$ and $-28 \%$ (Schiff et al. 1990). The isotopic differences observed between soil $\mathrm{CO}_{2}\left(\delta^{13} \mathrm{C}=-22 \%\right.$ during the summer $)$ and soil-respired $\mathrm{CO}_{2}$ at Harp Lake watershed $\left(\delta^{13} \mathrm{C}=\sim-27 \%\right)$ can be attributed to the effect of diffusion. This process enriches the soil $\mathrm{CO}_{2}$ by about $4.4 \%$ relative to the $\mathrm{CO}_{2}$ sources (respired $\left.\mathrm{CO}_{2}\right)($ Cerling 1984; Cerling et al. 1991). The $\delta^{13} \mathrm{C}$ values obtained during winter, which are closest to the isotopic composition of the sources, could be due to a reduction in $\mathrm{CO}_{2}$ loss by diffusion when the site is covered by snow.

Besides diffusion, the other possible mechanism that could shift the soil $\mathrm{CO}_{2}$ values seasonally is a change in the sources of soil $\mathrm{CO}_{2}$. Natelhoffer and Fry (1988) found some evidence that SOM is enriched in ${ }^{13} \mathrm{C}$ compared to the parent plant matter. Further, Dörr and Münnich (1986) postulated that lower ${ }^{14} \mathrm{C}$ values in soil $\mathrm{CO}_{2}$ in winter than in summer were due to the predominance of oxidation of SOM in winter as a source of $\mathrm{CO}_{2}$. Therefore, if SOM (more enriched $\delta^{13} \mathrm{C}$ values and maybe older compared to root respired $\mathrm{CO}_{2}$ ) is the dominant source of soil $\mathrm{CO}_{2}$ during the winter at Harp Lake basin, this should be reflected in the $\delta^{13} \mathrm{C}$ and ${ }^{14} \mathrm{C}$ content of the soil $\mathrm{CO}_{2}$. This hypothesis is highly speculative because no direct ${ }^{13} \mathrm{C}$ data are available to differentiate between soil $\mathrm{CO}_{2}$ generated by root respiration and by oxidation of organic matter.

A $\delta^{13} \mathrm{C}$ profile for SOM at Harp 4-21 subcatchment agrees with the data reported by Natelhoffer and Fry (1988), which show a $\delta^{13} \mathrm{C}$ change from $-29 \%$ at the surface to $-25 \%$ at a depth of 35 $\mathrm{cm}$ (Trumbore et al. 1992). However, ${ }^{14} \mathrm{C}$ results indicate that any $\mathrm{CO}_{2}$ produced by the oxidation of the deeper enriched ${ }^{13} \mathrm{C}$ organic carbon seems to be an insignificant component of the soil $\mathrm{CO}_{2}$. ${ }^{14} \mathrm{C}$ data of the SOM show recent carbon (114-118 pMC) at the very shallow part of the soil, with values close to $100 \mathrm{pMC}$ at a depth between 5 and $10 \mathrm{~cm}$. Older carbon, with ${ }^{14} \mathrm{C}$ content equal to or less than $80 \mathrm{pMC}$, is present at depths below $15 \mathrm{~cm}$ (Trumbore et al. 1992). In comparison, ${ }^{14} \mathrm{C}$ data obtained on soil $\mathrm{CO}_{2}$ show no significant changes in ${ }^{14} \mathrm{C}$ content between summer and winter months (Table 1). These values, ranging between 116.5 and $119 \mathrm{pMC}$, are similar to the ${ }^{14} \mathrm{C}$ data obtained on atmospheric $\mathrm{CO}_{2}$ and tree leaves from the same area (Table 1). The average ${ }^{14} \mathrm{C}$ activity in the atmospheric $\mathrm{CO}_{2}$ for 1990 in Canada was close to 118 pMC (Schiff et al. 1990). Thus, the soil $\mathrm{CO}_{2}$ carbon isotope data obtained at Harp Lake watershed suggest that diffusion is the dominant isotopic fractionating process in these soil environments, and the top $15 \mathrm{~cm}$ of the soil is the zone where $\mathrm{CO}_{2}$ is produced by oxidation of organic matter. The hypothesis that reduction of soil $\mathrm{CO}_{2}$ losses by diffusion explains the $\delta^{13} \mathrm{C}$ shift toward depleted values during winter is supported by the $\mathrm{CO}_{2}$ concentration profiles, which show an increase of $\mathrm{CO}_{2}$ concentration from December to March under continuous snowcover. 


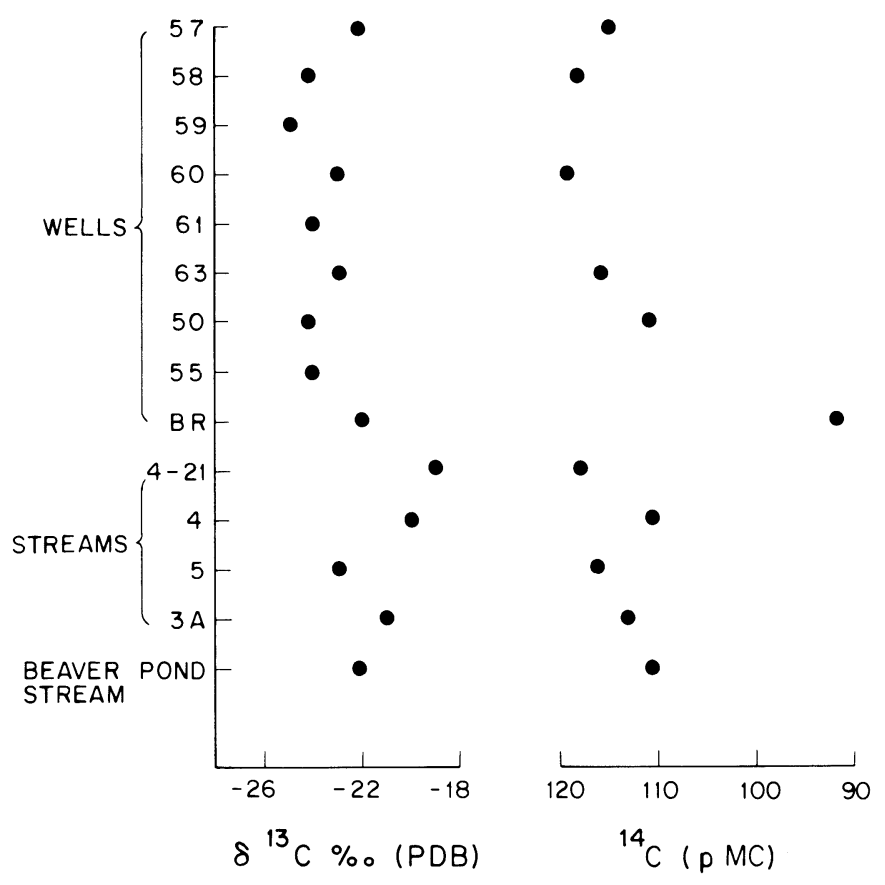

Fig. $4 .{ }^{13} \mathrm{C}$ and ${ }^{14} \mathrm{C}$ data for groundwater and streams, Harp Lake watershed

\section{Carbon Isotope Data in Groundwater}

Figure 4 shows the carbon isotopic composition of groundwater DIC. Wells sampled for groundwater are close to recharge areas (Wells 57, 58), in the middle of the basin (Wells 59,60,61, 63) and in the discharge areas close to the lake (Wells 50 and 55 and BR).

In general, the $\delta^{13} \mathrm{C}$ values of the groundwater DIC are very similar throughout the basin, ranging from -22 to $-24 \%$. This pattern is a reflection of the chemical reactions that control the production of DIC in the aquifer sediments at Harp Lake watershed.

The main reactions that produce DIC in groundwater are dissolution of carbonates and weathering of silicates. The extent of both reactions is a function of the concentration of soil $\mathrm{CO}_{2}\left(\mathrm{PCO}_{2}\right)$ in the recharge areas and the mineralogy of the sediments. These reactions generate DIC within a characteristic range in carbon isotopic composition.

Dissolution of carbonates can be described by

$$
\mathrm{CaCO}_{3}+\mathrm{CO}_{2}+\mathrm{H}_{2} \mathrm{O} \longrightarrow \mathrm{Ca}^{+2}+2 \mathrm{HCO}_{3}^{-} .
$$

This reaction under closed-system conditions generates DIC with an isotopic composition around $-11 \%$ and $59 \mathrm{pMC}$ in ${ }^{13} \mathrm{C}$ and ${ }^{14} \mathrm{C}$, respectively. This assumes a soil $\mathrm{CO}_{2}$ of $-22 \%$ and $118 \mathrm{pMC}$ and a carbonate of $0 \%$ and free of ${ }^{14} \mathrm{C}$. If this reaction occurs under open-system conditions, DIC should display $\delta^{13} \mathrm{C}$ values between $-19 \%$ and $-13 \%$, depending on the $\mathrm{pH}$ and temperature (Deines, Langmuir \& Harmon 1974; Wigley 1975) and a ${ }^{14} \mathrm{C}$ DIC activity close to 118 pMC.

In the case of weathering of silicates, for example, anorthite, 


$$
\mathrm{CaAl}_{2}\left(\mathrm{SiO}_{4}\right)_{2}+2 \mathrm{CO}_{2}+\mathrm{H}_{2} \mathrm{O} \longrightarrow \mathrm{Ca}^{+2}+\mathrm{Al}_{2} \mathrm{O}_{3}+2 \mathrm{SiO}_{2}+2 \mathrm{HCO}_{3}^{-}
$$

DIC generated by this reaction should have a ${ }^{14} \mathrm{C}$ activity similar to the soil $\mathrm{CO}_{2}$ and $\delta^{13} \mathrm{C}$ values enriched by about $1 \%$ relative to the soil $\mathrm{CO}_{2}(1 \%$ is the isotopic fractionation between gas and aqueous $\mathrm{CO}_{2}$ (Fontes 1983)). The ${ }^{13} \mathrm{C}$ data from Harp Lake watershed groundwater $\left(\delta^{13} \mathrm{C}=\right.$ $\sim-23 \%$ ) clearly indicate that the production of DIC is controlled by weathering of silicates. Although isotopic evidence of this process has been observed in groundwater (Hufen, Lau \& Buddemeir 1974; Gallo 1979), the Harp Lake data are the first to illustrate the effect of a pure silicate-weathering reaction, in the absence of carbonates, on the carbon isotopic composition of DIC in groundwater. This has important implications for the neutralization of acidic precipitation. Silicate weathering is much slower than carbonate weathering. The lack of even a small amount of residual carbonate undetectable by mineralogic analyses severely limits the production rate of acid neutralization capacity (ANC) in these catchments.

It can also be argued that DIC in Harp Lake groundwater reflects only dissolution of soil $\mathrm{CO}_{2}$ in recharge water, and not weathering. However, the geochemical evolution of the groundwater from recharge to discharge areas is clear evidence of weathering processes in the aquifer. The geochemical pattern shows increases in $\mathrm{pH}$, alkalinity, major cations and silica from shallow to deep groundwater and discharge areas (Dankevy et al., in press).

The main recharge events occur during spring melt and, to a lesser extent, during the fall (Hinton, Schiff \& English, ms.). The average $\delta^{13} \mathrm{C}$ of $-22 \%$ in the groundwater DIC agrees with this recharge scenario. It seems that warmer temperatures preceding the main spring event cause trees to become active, which should activate more production of soil $\mathrm{CO}_{2}$ from root respiration and/or $\mathrm{CO}_{2}$ produced during the winter. As soon as some snow cover recedes, diffusive $\mathrm{CO}_{2}$ losses should also increase, which enriches the soil $\mathrm{CO}_{2}$ in ${ }^{13} \mathrm{C}$. The April 1991 data on soil $\mathrm{CO}_{2}\left(\delta^{13} \mathrm{C}\right.$ values $\sim-22 \%$ ) confirm this. However, the slightly depleted $\delta^{13} \mathrm{C}$ values of around $-24 \%$ obtained in some groundwater suggest the contribution of recharge events occurring before the loss of snow cover during late winter/early spring, when the soil $\mathrm{CO}_{2}$ is characterized by $\delta^{13} \mathrm{C}$ values of $-25 \%$. These selective recharge events could be due to infiltration of heavy rains that percolate through the snow pack.

The ${ }^{14} \mathrm{C}$ data from these waters agrees with the ${ }^{13} \mathrm{C}$ scenario. All the wells closer to the recharge areas have ${ }^{14} \mathrm{C}$ values between 116 and $118 \mathrm{pMC}$. These values are similar to the ${ }^{14} \mathrm{C}$ data on soil $\mathrm{CO}_{2}$, atmospheric $\mathrm{CO}_{2}$ and tree leaves from the same area (Table 1). The average ${ }^{14} \mathrm{C}$ activity in the atmospheric $\mathrm{CO}_{2}$ for 1990 in Canada was close to $118 \mathrm{pMC}$ (Schiff et al. 1990). A comparison of the ${ }^{14} \mathrm{C}$ data of the groundwater at the discharge areas $(110 \mathrm{pMC})$ with the fallout ${ }^{14} \mathrm{C}$ curve for Canada suggests that these waters could have a residence time of at least 30 years between recharge and discharge areas (assuming piston flow). However, tritium data on groundwater indicate a shorter average residence time for the groundwater. It is more likely that the ${ }^{14} \mathrm{C}$ data reflect a mixture of waters with differing ${ }^{14} \mathrm{C}$ content prior to reaching discharge areas.

A groundwater component depleted in ${ }^{14} \mathrm{C}$ relative to shallow groundwater is indeed present in Harp Lake aquifer. Groundwater collected in a well tapping the bedrock has a ${ }^{14} \mathrm{C}$ activity of 92 pMC, which, when translated into ${ }^{14} \mathrm{C}$ years, yields a minimum residence time of about $1 \mathrm{ka}$. However, this water is tritiated, which indicates a younger average age of the water. The older ${ }^{14} \mathrm{C}$ component could be a mixture of a small amount of water of much longer residence time and containing high DIC and/or the input of older carbon from carbonate minerals. This last possibility can be analyzed, assuming the following scenarios: 1) the source of the older inorganic carbon is primary carbonate with a ${ }^{13} \mathrm{C}$ composition close to $0 \%$ and free of ${ }^{14} \mathrm{C}$; or 2 ) the source can be 
secondary carbonates with a ${ }^{13} \mathrm{C}$ composition close to $\mathrm{DIC}$ and with an unknown ${ }^{14} \mathrm{C}$ content. Because the ${ }^{13} \mathrm{C}$ remains unchanged despite a shift in the ${ }^{14} \mathrm{C}$ content (bedrock ${ }^{14} \mathrm{C}=92 \mathrm{pMC}$, mean $\delta^{13} \mathrm{C}=-22 \%$ ), the first possibility can be eliminated. For the second scenario, the boundaries for the $\delta^{13} \mathrm{C}$ isotopic composition of possible secondary carbonate should be between $-12 \%$ (in the case that primary carbonate and soil $\mathrm{CO}_{2}$ were the precursors of the secondary carbonate) and $-21 \%$, if only soil $\mathrm{CO}_{2}$ were the secondary carbonate precursor. Because the ${ }^{13} \mathrm{C}$ content of the bedrock water is similar to the other groundwater, the existence of ${ }^{13} \mathrm{C}$-enriched secondary carbonate can be eliminated. The only possibility left is ${ }^{13} \mathrm{C}$-depleted secondary carbonate, which implies a DIC generated by silicate weathering. However, it is unlikely that ${ }^{13} \mathrm{C}$-depleted secondary carbonate could have been deposited in these temperate forested watersheds, because the groundwater is very much undersaturated with respect to calcite (Dankevy et al., in press). Thus, the carbon isotope composition of the bedrock points to older groundwater in the basin, and suggests that the bedrock and tills were devoid of carbonate minerals before the onset of acid precipitation in the study area.

\section{Carbon Isotopic Composition of Stream Water}

The stream water shows the same carbon isotopic pattern as the groundwater. The $\delta^{13} \mathrm{C}$ DIC values range from $-19 \%$ to $-23 \%$. The slightly enriched $\delta^{13} \mathrm{C}$ values for some of the streams seem to be associated with DIC affected by isotopic exchange with atmospheric $\mathrm{CO}_{2}$. This process tends to enrich the DIC in ${ }^{13} \mathrm{C}$ (Broecker \& Walton 1959). The effect of this process can be observed in the evolution of the ${ }^{13} \mathrm{C}$ composition in streams during the complete season (Aravena \& Schiff 1990). Some streams change from $-22 \%$ at high flow during the rainy season, to $-15 \%$ at low flow during the dry season.

The ${ }^{14} \mathrm{C}$ activity for the stream water ranges from 119 pMC in Harp 4-21 to 110 pMC in Harp 4 and the beaver pond (Fig. 1). The high ${ }^{14} \mathrm{C}$ in stream water implies the input of recent groundwater to stream-flow generation. The slightly lower pMC in the beaver pond is a result of carbon cycling in this pond, probably related to conversion of DOC to DIC. DOC in the beaver pond is one of the oldest carbon pools in Harp Lake watershed (Schiff et al. 1990). Further, Harp 4 reflects the contribution of beaver-pond water and possibly the discharge of older groundwater (associated with bedrock) into the stream bed in areas close to the weir.

The input of groundwater is not the only factor controlling the DIC pool in Harp Lake streams. The presence of wetlands plays a significant role in both production and consumption of carbon in some subcatchments. This seems to be the case for the beaver pond and the Harp 5 subcatchment streams. The latter stream is the main source of DIC to Harp Lake (P. Dillon, unpublished data).

\section{CONCLUSIONS}

Soil $\mathrm{CO}_{2}$ concentration profiles in Harp Lake watershed, a forested basin located in the Canadian shield, are a result of changes in soil $\mathrm{CO}_{2}$ production and losses due to diffusion to the atmosphere and toward the water table. Soil $\mathrm{CO}_{2}$ production rates reach maxima and minima during summer and winter, respectively. Losses by diffusion tend to be reduced during winter because of the snow cover, which allows a slight accumulation of $\mathrm{CO}_{2}$ in the soil zone.

The carbon isotopic composition of soil $\mathrm{CO}_{2}\left(\delta^{13} \mathrm{C}=\sim-23 \%\right)$ in the summer reflects the carbon isotopic composition of the sources and isotopic fractionation due to losses by diffusion. The more depleted $\delta^{13} \mathrm{C}$ values $\left(\delta^{13} \mathrm{C}=\sim-25 \%\right)$ observed during winter are explained by a reduced diffusion 
rate because of the snow cover. These data confirm the role of diffusion as an isotope-fractionating process in soil $\mathrm{CO}_{2}$.

The carbon isotopic composition $\left({ }^{13} \mathrm{C},{ }^{14} \mathrm{C}\right)$ of the groundwater and streams indicates that silicate weathering by soil $\mathrm{CO}_{2}$ plays a dominant role in the generation of DIC and alkalinity in Harp Lake watershed. ${ }^{14} \mathrm{C}$ data show that, besides recent groundwater, an older groundwater component with less ${ }^{14} \mathrm{C}$ activity is also present in the bedrock. These data show the potential of using carbon isotopes, ${ }^{13} \mathrm{C}$ and ${ }^{14} \mathrm{C}$, to determine groundwater input from bedrock into surface water, and also rule out the existence of primary carbonate minerals in bedrock and tills before the onset of acid rain in the study area.

Selective and significant recharge events inferred from the carbon isotope pattern of the groundwater were identified at the end of the winter. This finding has important implications for ${ }^{14} \mathrm{C}$ dating of groundwater systems. One important parameter for geochemical models used to correct ${ }^{14} \mathrm{C}$ data in groundwater is the ${ }^{13} \mathrm{C}$ composition of the recharge water, generally inferred from the ${ }^{13} \mathrm{C}$ composition of the soil $\mathrm{CO}_{2}$. The difference in $\delta^{13} \mathrm{C}$ between selective recharge and spring and fall events is as much as $4 \%$.

\section{ACKNOWLEDGMENTS}

Funding was provided by the Ontario Ministry of the Environment and the Natural Sciences and Engineering Research Council of Canada. We thank Lem Scott and Jim Jones of the Dorset Research Centre (OME) for logistical support during the study.

\section{REFERENCES}

Aravena, R. and Schiff, S. L. $1990 \mathrm{CO}_{2}$ production and carbon cycling in Precambrian Shield Watersheds. In Proceedings of the Technology Transfer Conference. Environment Ontario 1: 177-180.

Broecker, W. S. and Walton, A. 1959 The geochemistry of C-14 in fresh water systems. Geochimica et Cosmochimica Acta 16: 15-34.

Cerling, T. E. 1984 The stable isotopic composition of modern soil carbonate and its relationship to climate. Earth and Planetary Science Letters 71: 229-240.

Cerling, T. E., Quade, J., Wang, Y. and Bowman, J. R. 1989 Carbon isotopes in soils and paleosols as paleoecologic indicators. Nature 341: 138-139.

Cerling, T. E., Solomon, K. D., Quade, J. and Bowman, J. R. 1991 On the isotopic composition of carbon in soil carbon dioxide. Geochimica et Cosmochimica Acta 55: 3403-3405.

Cicerone, R. J. and Oremland, R. S. 1988 Biochemical aspects of atmospheric methane. Global Biogeochem ical Cycles 2(4): 299-327.

Dankevy, S. N., Schiff, S. L., English, M. and Dillon, P. $\mathrm{J}$., in press, Groundwater flow and chemistry in a small acid-stressed subcatchment in the Canadian Shield. In Proceedings of the NHRI Symposium on Groundwater Contamination, National Hydrologic Research Institute, Environment Canada.

Davis, J. C., Proctor, I. D., Southon, J. R., Caffee, M. W., Heikkinen, D. W., Roberts, M. L., Turteltaub, K. W., Nelson, D. E., Loyd, D. H. and Vogel, J. S. 1990
LLNL/UC AMS facility and research program. In Yiou, F. and Raisbeck, G. M., eds., Proceedings of the 5th International Conference on Accelerator Mass Spectrometry. Nuclear Instruments and Methods B52: 269-272.

Deines, P. 1980 The isotopic composition of reduced organic carbon. In Fritz, P. and Fontes, J.-C., eds., Handbook of Environmental Geochemistry V1: Amsterdam, Elsevier: 329-406.

Deines, P. D., Langmuir, D. and Harmon, R. S. 1974 Stable carbon isotope ratio and the existence of a gas phase in the evolution of carbonate groundwaters. Geochimica et Cosmochimica Acta 38: 1147-1164.

Dillon, P. J., Jeffries, D. S., Snyder, W., Reid, R., Yan, N. D., Evans, D. and Moss, J. 1978. Acid precipitation in South-Central Ontario: Recent observations. Journal of Fisheries Research Board Canada 35(6): 809-815.

Dörr, H. and Münnich, K. O. 1980. Carbon-14 and carbon-13 in soil $\mathrm{CO}_{2}$. In Stuiver, M. and Kra, R. S., eds., Proceedings of the 10 th International ${ }^{14} \mathrm{C}$ Conference. Radiocarbon 22(3): 909-918.

1986 Annual variation of the ${ }^{14} \mathrm{C}$ content of soil $\mathrm{CO}_{2}$. In Stuiver, M. and Kra, R. S., eds., Proceedings of the 12 th International ${ }^{14} \mathrm{C}$ Conference. Radiocarbon 28(2A): 338-345.

1987 Annual variation in soil respiration in selected areas of the temperate zone. Tellus 39B: 114-121. 
Fontes, J.-C. 1983 Dating of groundwater. In Guidebook to Nuclear Techniques in Hydrology. IAEA, Vienna. Technical Report Series 91: 285-299.

Gallo, G. 1979 Utilization complementaire des isotopes de milieu et de l'hydrochimie pour l'etude hydrogeologique des eaus souterraines de la Region de Ribeirao Preto (Brasil). In Isotope Hydrology 2: 367-407. IAEA, Vienna.

Hedges, J. I., Clark, W. A., Quay, P. D., Richey, J. E., Devol, A. H. and Santos, M. 1986 Composition and fluxes of particulate organic material in the Amazon river. Limnology and Oceanography 31: 717-738.

Hufen, T. H., Lau, L. S. and Buddemeir, R. W. 1974 Radiocarbon, ${ }^{13} \mathrm{C}$ and tritium in water samples from basaltic aquifers and carbonate aquifers on the Island of Oahu, Hawaii. In Proceedings, Isotope Techniques in Groundwater Hydrology 2: 111-127. IAEA, Vienna.

Hinton, M. J., Schiff, S. L. and English, M. C. 1992 Physical properties governing groundwater flow in a glacial till catchment. Journal of Hydrology, in press.

Jeffries, D. S. and Snyder, W. R. 1983 Geology and geochemistry of the Muskoka-Haliburton study area. Dorset Research Centre Ministry of the Environment. Data Report DR 83/2: 101 p.

Kirkwood, D. E. and Nesbitt, H. W. 1991 Formation and evolution of soils from an acidified watershed: Plastic Lake, Ontario, Canada. Geochimica et Cosmochimica Acta 55(5): 1295-1308.

Natelhoffer, K. J. and Fry, B. 1988 Control on the natural nitrogen-15 and carbon-13 abundances in forest soil organic matter. Soil Science of America Journal 52: 1633-1639.

Quay, P. D., Emerson, S. R., Quay, B. M. and Devol, A. H. 1986 The carbon cycle for Lake Washington A stable isotope study. Limnology and Oceanography 31(3): 596-611.
Reardon, E. J., Allison, G. B. and Fritz, P. 1979 Seasonal chemical and isotopic variations of soil $\mathrm{CO}_{2}$ at Trout Creek, Ontario. Journal of Hydrology 43: 355-371.

Rustad, S., Christophersen, N., Seip, H. M. and Dillon, P..J. 1986 Model for streamwater chemistry of a tributary to Harp Lake, Ontario. Canadian Journal of Fisheries and Aquatic Sciences 43: 625-633.

Scheider, W. A., Jeffries, D. S. and Dillon, P. J. 1979 Effect of acid precipitation on Precambrian freshwaters in Southern Ontario. Journal of Great Lakes Research 5(1): 45-51.

Schiff, S. L., Aravena, R., Trumbore, S. E. and Dillon, P. J. 1990 Dissolved organic carbon cycling in forested watersheds: A carbon isotope approach. Water Resources Research 26(12): 2949-2957.

Seip, H. M., Seip, R., Dillon, P. J. and DeGrosbois, E. 1985 Model of sulphate concentration in a small stream in the Harp Lake catchment, Ontario. Canadian Journal of Fisheries and Aquatic Sciences 42: 927-937.

Solomon, D. K. and Cerling, T. E. 1987 The annual carbon dioxide cycle in a montane soil: observations, modeling and implications for weathering. Water Resources Research 23: 2257-2265.

Stuiver, M. and Polach, H. A. 1977 Discussion: Reporting of ${ }^{14} \mathrm{C}$ data. Radiocarbon 19(3): 355-363.

Trumbore, S. E., Schiff, S. L., Aravena, R. and Elgood, R. 1992 Sources and transformation of dissolved organic carbon in a forested catchment: The role of soils. Radiocarbon, this issue.

Wigley, T. M. L. 1975 Carbon-14 dating of groundwater from closed and open systems. Water Resources Research 11: 324-328. 